Please do not remove this page

RMIT

UNIVERSITY

\title{
Industry superannuation funds: a new kind of mutual
}

Mees, Bernard; Paul, Aron

https://researchrepository.rmit.edu.au/esploro/outputs/9921860908501341/filesAndLinks?institution=61RMIT_INST\&index=null

Mees, B., \& Paul, A. (2017). Industry superannuation funds: a new kind of mutual. Labour History, 112, 25-44. https://doi.org/10.5263/labourhistory.112.0025

Document Version: Accepted Manuscript

Published Version: https://doi.org/10.5263/labourhistory.112.0025

Repository homepage: https://researchrepository.rmit.edu.au

(c) 2017 Australian Society for the Study of Labour History

Downloaded On 2023/04/26 15:16:48 +1000 
Thank you for downloading this document from the RMIT Research Repository.

The RMIT Research Repository is an open access database showcasing the research outputs of RMIT University researchers.

RMIT Research Repository: http://researchbank.rmit.edu.au/

\section{Citation:}

Mees, B and Paul, A 2017, 'Industry superannuation funds: a new kind of mutual', Labour History, vol. 112, pp. 25-44

See this record in the RMIT Research Repository at:

https://researchbank.rmit.edu.au/view/rmit:43701

Version: Accepted Manuscript

\section{Copyright Statement:}

(c) 2017 Australian Society for the Study of Labour History

Link to Published Version:

http://dx.doi.org/10.5263/labourhistory.112.0025 


\title{
Industry Superannuation Funds: A New Kind of Mutual
}

\author{
Bernard Mees and Aron Paul (RMIT)
}

\begin{abstract}
At the time of the founding of the industry superannuation funds, the Australian retirementsavings market was dominated by insurance mutuals. In the early $1980 \mathrm{~s}$, less than half the workforce was covered by occupational superannuation and unions saw the insurance mutuals, created in the nineteenth century, as part of the problem in this widespread market failure. When establishing industry-wide schemes, union leaders largely eschewed the language associated with the "old" mutuals that had become key pillars of the established financial sector. In framing their appeal to members, the trustees and managers of the industry funds appealed instead to new expressions, such as "all profit to members". Industry funds also developed a model of 50/50 employer/employee trusteeship or "equal representation" not as an ideological prescription, but as a pragmatic way of dealing with opposition to the schemes by employers. The trustees and managers of industry superannuation funds contrasted rather than associated themselves with the "old mutuals" which, at the time, were not seen as reflecting the unions' ideal of an industrial partnership. However, with the decline and demutualisation of the largest old insurance mutuals in the $1990 \mathrm{~s}$, the industry funds began to appropriate the language of mutualism. This appropriation took place within the context of a perceived need to maintain a collective identity and purpose in the changing superannuation marketplace.
\end{abstract}

\section{Introduction}

Mutualism as a philosophy originated as a critique and response to capitalism. Advocated by nineteenth-century socialists such as Robert Owen and Pierre-Joseph Proudhon, mutualism historically sought to establish a "third way" between liberal market capitalism and statecentred socialism. ${ }^{1}$ Since the 1990 s, Australian industry superannuation funds, and especially the associated institutions they own such as Members Equity Bank (ME), IFM Investors and Industry Super Australia have embraced the philosophy of mutualism. They have done so in a manner quite independent of calls to embrace a new kind of (public policy) mutualism or "third way" as has been the case in the United Kingdom and elsewhere. ${ }^{2}$ Yet the first use of the description "new mutual" to refer to industry superannuation dates to well after the funds had been established -- and was adopted as the outcome of a process of identity formation

\footnotetext{
${ }^{1}$ Robert Owen, Report to the County of Lanark (Glasgow: The University Press, 1821), 28-30; Pierre-Joseph Proudhon, Manuel du spéculateur à la bourse, 5th ed. (Paris: Garnier, 1857), 481-82.

2 Anthony Giddens, The Third Way and Its Critics (Cambridge: Polity, 2000); Johnston Birchall, The New Mutualism in Public Policy (London: Routledge, 2001).
} 
and development that occurred in the not-for-profit institutions which emerged during the formative years of the industry superannuation movement.

In outlining the development of industry superannuation funds as "new mutuals", this paper contributes to understandings of how mutualist philosophy and identity can endure in the context of an economic landscape seemingly hostile to communitarian ideals. The emergence of industry superannuation highlights the nature of mutualism as a pragmatic "third way" grounded in defending the interests of a defined community -- in this case, predominantly blue-collar and unionised workers. Industry superannuation can be conceptualised as consistent with the basic principles of Proudhon who saw mutualism as a method of equalising the power of workers with capital or the state, with the aim that "la richesse devienne la condition générale" (wealth becomes the general condition). ${ }^{3}$ The combination in mutualist philosophy of communitarian political action on the one hand and the validation of individual property rights on the other, make it a fitting framework for a sector that, as this paper demonstrates, owes its philosophical thinking and organisational development to a striking intersection of players across both the labour movement and the private mutual/insurance market.

\section{The Emergence of Industry Superannuation}

Occupational retirement savings are not characterised as pensions in Australia, but are instead paid through the legal vehicle of superannuation, the traditional British term for retirement and retirement allowances. ${ }^{4}$ The Australian superannuation market is also particularly characterised by the prevalence of industry-wide private-sector funds jointly governed by union officials and the nominees of employer associations. Superannuation provision had formerly been dominated by corporate and public-sector schemes, much as occupational pensions still are in Britain and North America, but since the 1980s most company schemes have been wound up, with their accumulated benefits either being rolled over into industry funds or corporate master trusts run by for-profit (or "retail") providers. There are, accordingly, five types of superannuation scheme presently: industry funds, public-sector schemes, corporate plans, retail master trusts and small or self-managed superannuation funds (SMSFs). ${ }^{5}$

The Australian industry superannuation sector is the most recent to develop. It first emerged in the 1980s and has constructed a collective sense of culture and identity through

\footnotetext{
${ }^{3}$ Pierre-Joseph Proudhon, De la justice dans la révolution et dans l'église (4 vols, Paris: Garnier, 1858), I, 203.

${ }^{4}$ The 1822 imperial superannuation act ( 3 Geo. IV, c. 51) distinguished between military and naval "pensions" and civil service "superannuations".

${ }^{5}$ APRA, "Celebrating 10 Years of Superannuation Data Collection 1996-2006”, APRA Insight 2 (2007), 18-20.
} 
the memory and history shared by its founding figures, many of whom came into the retirement-savings industry via the union movement. While the industry superannuation funds espouse mutualistic principles, the sector defines itself in opposition to the "old" life insurance mutuals that once dominated private-sector superannuation, and has in turn tried to create a new kind of mutualism in retirement-savings provision. Narratives of collective identity are used to defend the industry funds against threats to their mutualistic ethos and standing. The funds established in the 1980s are "alternative organisations" (i.e. they are not listed companies and do not return profits to shareholders) and represent a new kind of wealth management provider. They employ a different business model to those that had prevailed in the private sector previously and the development of their association with mutualism is best understood in terms of the recent "historical turn" of organisation studies. ${ }^{6}$ Having its origin in the labour movement, the development of the industry superannuation sector also reflects an outcome of the increased number of economics graduates that came into the Australian union movement in the 1970s, the "corporatist" nature of decision making under the Hawke Labor government and above all an attempt to provide a new basis for employee welfare through the establishment of a "social wage". A new language and identity was adopted at the time of the sector's formation that has evolved since the 1980s, but which emerged and developed in a manner independent of those witnessed elsewhere internationally. ${ }^{7}$

The industry funds were established at a time when the finance sector was first beginning to demutualise. Over the course of the 1990s, the life insurance providers City Mutual, National Mutual, Colonial Mutual and the Australian Mutual Provident Society (AMP) -- all organisations founded in the nineteenth century -- either merged or became listed entities. At the same time, however, the industry superannuation sector began to claim an identity as mutualistic. Not legally constituted as mutuals, the industry super funds and the associated collective institutions they own took on a similar role to the "old" mutuals as "third-sector" organisations. As politicians of all stripes claimed that a mutual structure was no longer appropriate for a finance company, during the 1990s an "all-profit-to-members" identity was created for the industry funds in opposition to what was seen as a declining mutual sector. With the older tradition of mutualism seemingly unable to survive the modernisation of the finance industry a new form of member-focused mutualism developed in its place. ${ }^{8}$

\footnotetext{
${ }^{6}$ Rasmus K. Hartmann, "Subversive Functionalism: For A Less Canonical Critique in Critical Management Studies", Human Relations 67, no. 5 (2014), 611-32; Michael Rowlinson, Andrea Casey, Per Hansen and Albert Mills, "Narratives and Memory in Organizations", Organization 21, no. 4 (2014), 441-46.

${ }^{7}$ Gwynneth Singleton, The Accord and the Australian Labour Movement, Melbourne: Melbourne University Press, 1990; Diana Shaw, "Trade Union Participation in Public Policy: The Rise and Demise of Australia's National Retirement Income Regime" (PhD diss., University of NSW, 1992).

${ }^{8}$ Monica Keneley, "Demutualisation in the Life Insurance Industry: A Preliminary Assessment", Economic Papers 21, no. 2 (2002), 66-79; Monica Kenneley, "The Demise of the Mutual Life Insurer: An Analysis of the
} 
At the time of the founding of the industry funds in the 1980 s, only 40 per cent of the Australian workforce had been covered by superannuation, and an even higher proportion of retired blue-collar workers were principally reliant on personal savings supplemented by a federal age pension that was widely criticised as not adequate to provide "dignity in retirement". ${ }^{9}$ Part-time and casual employees (most of whom were women) were largely excluded from the paternalist and "welfarist" model of occupational superannuation that covered 72 per cent of high-income earners but only 30 per cent of those on more moderate wages. ${ }^{10}$ In the $1980 \mathrm{~s}$, however, the industrial wing of the labour movement decided to make superannuation "union business", and beginning in the building industry, began a push to establish a universal entitlement to superannuation. ${ }^{11}$ The original industry superannuation funds were established at a time of close union collaboration with the Australian Labor Party (ALP) through the Prices and Incomes Accord, originally established in 1982-83 between the ALP and the national peak body the Australian Council of Trade Unions (ACTU). The Accord process had been started while the ALP were in opposition under the leadership of Bill Hayden, with the ALP's treasury and industrial relations spokesman Ralph Willis and the ACTU's assistant secretary Bill Kelty the key actors in its drafting. ${ }^{12}$ An economics graduate of Melbourne's La Trobe University, Kelty was a former research officer with the Federated Storemen and Packers' Union, and with the support of the Storemen and Packers' general secretary Simon Crean had managed to get superannuation (briefly) mentioned in the first Accord..$^{13}$ The Storemen and Packers' Union had done much to advocate for superannuation since they had set up the Labour Union Co-operative Retirement Fund (LUCRF) in 1978. ${ }^{14}$ Crean, an economics and law graduate of Melbourne's Monash University, had missed the chance to follow his father Frank into parliament in 1977, failing to win pre-selection for the seat of Melbourne Ports, but was so successful at the Storemen and Packers he had managed to be elected junior Vice-President of the ACTU in 1981. Kelty unexpectedly become ACTU

Impact of Regulatory Change on the Performance of Australian Life Insurers in the 1990s", Accounting History 15 (2010), 65-91.

${ }^{9}$ Richard I. Downing, "Portability and Preservation of Benefits", Superfunds, December 1970, 11-15; ACTU, "Superannuation", circular no. 359, 19 October 1984, B.U.S. Superannuation, N129/310, Noel Butlin Archive Centre (NBAC).

${ }^{10}$ ACTU, "Superannuation", 1984; Nikola Balnave, "Industrial Welfarism in Australia, 1890-1965" (PhD diss., University of Sydney, 2002).

${ }^{11}$ Diana Olsberg, Ageing and Money: Australia's Retirement Revolution (St Leonards, NSW: Allen \& Unwin, 1997); Easson, "Present at the Creation", 75-96; Garry Weaven, "Workers' Capital: The Story of Industry Funds and Australia's Superannuation Revolution", Foenander Lecture, Melbourne University, 16 November 2016.

${ }^{12}$ ALP/ACTU, "Statement of Accord by the Australian Labor Party and the Australian Council of Trade Unions regarding Economic Policy", February 1983; Singleton, The Accord and the Australian Labour Movement, 13454.

${ }^{13}$ Mary Easson, "Present at the Creation: The Origins of the Australian System of Superannuation" (MPhil thesis, University of NSW, 2013), 44.

${ }^{14}$ William A. Landeryou, "The Union Attitude to Superannuation", Superfunds, December 1978, 30-31; Simon Crean, "How One Union Won An Improved Super Scheme", Australian Financial Review, 24 September 1979. 
secretary in early 1983 after his predecessor Peter Nolan stood down when a $\$ 600,000$ cost overrun had emerged with the purchase of ACTU House in Swanston St, Melbourne. ${ }^{15}$ While Kelty and Crean only managed to win a vague commitment to superannuation in the first Accord, the ACTU push for superannuation led to a more comprehensive superannuation agreement being struck with the federal government in the second iteration of the Accord in late $1985 .{ }^{16}$

Yet from the date of its election in March 1983, the Hawke Labor government had set about a program of economic liberalisation accompanied by a series of social wage productivity trade-offs. These included the establishment of universal health care (Medicare) and after 1985 also compulsory occupational superannuation. ${ }^{17}$ Industry superannuation was won through bargaining and industrial action, but with the support of the Hawke government under the auspices of the Accord process. Kelty and the new Treasurer Paul Keating came to form a particularly close friendship after the federal government had come around to supporting the ACTU's push for universal super. ${ }^{18}$ The industry-wide funds created at the time, however, were not traditional labour-owned firms, credit co-operatives or finance mutuals. Constituted legally as trusts controlled by corporate trustees, the relationship of the funds with mutualism was initially a complex and often antagonistic affair, with a mutualist identity not coming to be articulated until many years after the funds were created.

\section{Old and New Mutuals}

The old insurance mutuals had been founded in the nineteenth century and reflected the British fascination with the importance of life assurance. Mutualism was promoted as a superior, collective way to provide for the widows and surviving children of male breadwinners at a time when the membership of friendly societies was at its historic peak. ${ }^{19}$ Beginning from the 1950s, however, the old insurance mutuals had expanded into superannuation provision as access to an occupational pension plan increasingly became a standard expectation of corporate staff, by offering endowment assurance policies and helping companies develop discrete corporate superannuation funds. ${ }^{20}$

\footnotetext{
${ }^{15}$ Keith Martin, "Prices-income Deal To Be Reviewed”, Sydney Morning Herald, 21 January 1983, 22.

${ }^{16}$ ALP/ACTU, "Agreement between the Government and the ACTU regarding Implementation of the Accord over the Next Two Years" (Accord Mark II), September 1985.

17 Anne-Marie Boxall and James Gillespie, Making Medicare: The Politics of Universal Health Care in Australia (Sydney: UNSW Press 2013); Easson, "Present at the Creation", 47-52.

${ }^{18}$ Paul Kelly, The March of Patriots: The Struggle for Modern Australia (Carlton, Vic.: Melbourne University Press, 2009), 145.

${ }^{19}$ Arthur C. Gray, Life Insurance in Australia: An Historical and Descriptive Account (Melbourne: McCarron Bird 1977); David D. Green and Lawrence G. Cromwell, Mutual Aid or Welfare State: Australia's Friendly Societies (Sydney: Allen \& Unwin, 1984).
} 
Yet moving into superannuation had increasingly made profit-sharing among "participating" policyholders of the mutuals problematic, as superannuation services grew to become a third or more of the business generated by the major life-insurance providers. The typical corporate superannuation arrangement at the time involved both employers and employees making contributions based on a percentage of salary which the life insurance mutuals would invest and use to pay a retirement pension or death benefit according to a benefit formula (as a "defined benefit" or "benefit promise"). All profits made by the mutuals were supposed to be distributed to members annually, but the problems associated with distributing profits to superannuation policyholders were exacerbated by developments in investment practices over the course of the 1960s and 70s. Where a holder of an endowment policy could be treated like the purchaser of any other insurance product, superannuation fund members often belonged to discrete company schemes, with the trustees of the funds being the (direct) clients of the insurance mutual. Beginning in the 1960s, National Mutual had started offering corporate trustees investment choice, allowing them to choose allocations between equities and property, fixed interest and government bonds (their EFG investment system) -- effectively allowing them to opt out of the collective mutual structure. ${ }^{21}$ The investment arrangements and partnering with firms particularly common in the superannuation area made the calculation of distributions for mutual policyholders increasingly complex and fraught. ${ }^{22}$ By the 1980 s many of the old insurance mutuals had responded by retaining proportions of their reserves -- "squirrelling away" their profits from policyholders. ${ }^{23}$ The complexities involved in developing their superannuation businesses, moving from individual to group clients, made the life offices increasingly opaque and dependent on the interests of corporate trustees rather than the beneficiaries of the superannuation schemes they managed.

By the 1980s, the insurance mutuals no longer seemed to represent the interests of many of the members of the public with which they had financial relationships. Their investment functions had been centralised into funds management arms separate from their insurance and superannuation administration businesses, and the emergence of rival "boutique" fund managers added external competition in one of the most profitable aspects of superannuation provision. ${ }^{24}$ The outsourcing of the sales forces of the life insurance mutuals to the new industry of financial planners through the use of trailing commissions also added a

\footnotetext{
${ }^{20}$ L.L. Robison et al., A Century of Life: The Story of the First One Hundred Years of the National Mutual Life (Melbourne: NMLA, 1969), 125-26; Peter C. Wickens, The City Mutual Story: A Century of Service to Australians 1878-1978 (Sydney: City Mutual, 1979), 127-34; Balnave, 93.

${ }^{21}$ Robison et al., A Century of Life, 126.

${ }^{22}$ Geoffrey Blainey, A History of the AMP, 1848-1998 (St Leonards, NSW: Allen \& Unwin, 1999), 329.

${ }^{23}$ Sandy Grant, interview, 27 July 2015.

${ }^{24}$ Monica Keneley, 'The Development of the Institutional Investor: The Case of Australian Life Insurers 194585', Australian Economic History Review 52 (2012), 270-92.
} 
level of fragmentation and complexity to their business models that seemed at odds with the philosophy of mutualism. ${ }^{25}$ During the $1980 \mathrm{~s}$, the life offices were seen by unions as part of the reason for the widespread shortcomings of superannuation. Scandals such as the Miller Rope, Twine and Textiles case of 1977/78 were blamed on the behaviour of the life insurance companies who administered and managed the plans, with insurance companies seeing the interests of the members of corporate schemes as less important than those of the corporate clients at whose behest the schemes had originally been designed. ${ }^{26}$ As an extension of corporate welfarism, the involvement of the life offices in superannuation conflicted with the ethos on which the old mutuals had been founded.

\section{The Legacy of Mutualism}

In 1969 the Victorian Bolte government had invited a Canadian expert, Lawrence Coward, to prepare a report on the reform of superannuation. Coward was reported in the press at the time saying "I am amazed that employees' rights on superannuation are so pitifully weak here", but nothing had changed by the early 1980s. ${ }^{27}$ In the Miller Rope case, the receivers of the insolvent company, James Miller Holdings, had originally decided to pay out all employees an equitable share of the remaining moneys in the underfunded company superannuation scheme and had let the employees go in reverse order of their seniority and age, giving those least likely to be able to find work the longest reprieve from retrenchment. Following a successful challenge to the Victorian Supreme Court by the directors of the company, National Mutual ended up paying out most of the benefits from the superannuation scheme to Miller's directors and other executive staff, not the 41 fund beneficiaries who the receivers had retrenched last because they were nearest retirement age. ${ }^{28}$ Another scandal in 1971 at Caterpillar of Australia Ltd saw 98 retrenched workers not receive the benefits they had been promised by the company. Like most defined benefit schemes, the Caterpillar employee retirement plan had been designed so that members only received the contributions made by the employer if they were close to reaching retirement age -- the employer contributions otherwise were used to subsidise the benefits paid to the longest-serving members of staff. The trust deed of the fund provided for less generous benefits than those stipulated in the company's employee retirement plan booklet, meaning the retrenched

\footnotetext{
${ }^{25}$ Bernard Mees, Monica Wehner and Pamela Hanrahan, Fifty Years of Managed Funds in Australia (Sydney: IFSA/Melbourne: University of Melbourne, 2005), 82-88.

${ }^{26}$ James Miller Holdings Ltd v Graham and Ors (1978) 3 ACLR 604 (Vic); Greg Sword, quoted in "Both Sides Jittery on Super", The Age, 13 December 1985, 16.

${ }^{27}$ Lawrence Coward, quoted in Peter Cairns, "He's Workers' 'Super' Man”, The Herald, 29 March 1969, 21.

${ }^{28}$ Jennifer Eastick, "James Miller Holdings Ltd v Graham and Others", Melbourne University Law Review 12 (1979), 121-26.
} 
workers only received their own contributions back (without interest) when they were let go. ${ }^{29}$ Frustration at the way company superannuation funds were designed and run by the life offices was a key reason why the union movement decided to get into the business of running industry schemes. The ACTU and the building unions would reform the way in which the old mutuals had previously provided superannuation services in a manner that allowed the industry funds to access the technical competency that the life offices had developed, but which let the trustees of the new multi-employer schemes remain in control.

When establishing funds such as Building Unions Superannuation (BUS), union leaders treated with considerable distrust the old mutuals that had become key pillars of the established financial sector. The main insurance mutuals had longstanding links with the Liberal Party and were staffed overwhelmingly by Coalition voters. ${ }^{30}$ The Whitlam government's proposal to establish a national insurance office had led to a particularly strong anti-ALP sentiment developing in the life insurance sector -- little common ground existed between the old mutuals and the union movement. ${ }^{31}$ When the ACTU approached the insurance industry in early 1984 to help with the administration of BUS, they were treated with considerable suspicion. Many of the Colonial Mutual staff who worked with the ACTU and the building unions in setting up BUS were initially concerned about going over to the "other side" -- that they were moving into an environment where employers were facing compulsion as opposed to the established environment which was based around sales. ${ }^{32}$ But the second iteration of the Accord reached with the Hawke government in late 1985 saw a rapid broadening of superannuation coverage across the unionised workforce. And the three largest life insurance mutuals -- Colonial Mutual, National Mutual and the AMP Society -each established specialist industry superannuation administration arms in order to build better relationships with the industry funds. ${ }^{33}$

Union leaders at the time characterised their approach to fund governance as a partnership between unions and employer associations. BUS had originally been established in May 1984 with only (five) union trustees -- with the ACTU's Garry Weaven serving as the (non-voting) chair. ${ }^{34}$ Two employer association representatives were later appointed to the board, a number that was later expanded to five. ${ }^{35}$ Notwithstanding that BUS was a union initiative, Colonial Mutual played an important role in establishing the fund. Its staff sat in on

\footnotetext{
${ }^{29}$ Victorian Hansard, 18 November 1971, 2826-27.

${ }^{30}$ Ray Jureidini, "Life Insurance and Superannuation: A Sociological Study of Moral Values in Economic Life" (PhD dissertation, Flinders University, 1987), 199-200.

${ }^{31}$ Blainey, A History of the AMP, 281.

${ }_{32}$ Peter Gebert, in Patricia Holt (ed.), An Oral History of $C+B U S$ : The Construction and Building Industry's Superannuation Fund (Melbourne: National Centre for Australian Studies, Monash University, 1996), 48.

${ }_{33}$ Phillip D. Jack, "Jacques Martin Grabs Union Business", Australian Business, 12 March 1986, 34-35; Brendan Donohoe, "Life Companies Chasing Union Business", The Age, 22 May 1987, 55.

${ }^{34}$ Minutes, Building Unions Superannuation, 29 May 1984, B.U.S. Scheme N130/1052, NBAC.

${ }^{35}$ Minutes, Building Unions Superannuation, 17 July 1984, B.U.S. Scheme, N130/1052, NBAC.
} 
the early meetings of BUS, they offered advice on the duties of trustees, the design of the trust deed and the publicity materials to be produced. In addition a computer terminal was installed in ACTU House so that the ACTU's fund coordinator Mike McKay could have access to Colonial's administration database. ${ }^{36}$ The ACTU had received tenders to help set up BUS from Colonial Mutual, AMP and National Mutual -- most of the other life offices had treated the ACTU's approaches with apprehension or disdain. Colonial Mutual was chosen as it had already established a specialist superannuation administrator Jacques Martin (named after Colonial's first managing director), with well-developed computer facilities (designed by Campbell and Cook's Co-Cam Computer Services), whereas AMP and National Mutual had instead attempted to "bundle" their administration proposals with life insurance and investment services. ${ }^{37}$ The building unions and ACTU preferred the unbundled tender of Jacques Martin as they set about creating the first large multi-employer fund in the country. Within 18 months, BUS had become the largest private superannuation scheme in Australia, with more than 100,000 members and yearly contributions in excess of $\$ 50$ million.

Weaven and his secretary Ian Court had both been to university together (studying economics in the same year as Kelty at La Trobe University) and Weaven had recruited Court (from Repco) to the Municipal Officers Association in the 1970s where both became involved with superannuation. Weaven was still a member of the Victorian Local Authorities Superannuation Board (now Vision Super) when he joined the ACTU and brought his considerable public-sector superannuation experience to bear on the industry funds he chaired ${ }^{38}$ Jacques Martin would help McKay and the interstate superannuation coordinators as the union officials concerned gained experience in running the country's first large industry-wide superannuation schemes.

The influence of the life offices was even more profound at other industry funds. While the earlier union-established schemes such as the Pulp and Paper Workers' Superannuation Fund (founded in 1974) and the Storemen and Packers' LUCRF had been self-administered, most of the funds established after the creation of BUS took the outsourced BUS system as their model, typically using Jacques Martin Industry as their administrator or approaching a different life office to help them establish their scheme. The Pulp and Paper Workers' Federation had employed a former banking executive Ian McInerny as their fund secretary and McInerny became involved with both the ACTU, when it established its superannuation committee in 1979, as well as the Meatworkers (under Wally Curran) when they set up the Meat Industry Employees' Provident Fund in 1981. ${ }^{39}$

\footnotetext{
${ }^{36}$ Minutes, Building Unions Superannuation, 11 October 1984, B.U.S. Scheme, N130/1054, NBAC.

${ }^{37}$ William J. Kelty to insurance companies, 5 March 1984; Jacques Martin, tender, April 1984, and National Mutual, tender, April 1984, B.U.S. Scheme, N130/1051, NBAC.

${ }^{38}$ Victoria Government Gazette, 19 August 1981, 2771; Court in Holt (ed.), Oral History of C $+B U S$, 16; Ian Court, interview, 18 November 2015; Weaven, "Workers' Capital”.
} 
The Liquor Trades Unions' Portable Liquor Union Superannuation scheme (PLUS) was established with the help of Jacques Martin and the liquor industry continued to use the Colonial Mutual subsidiary as an administrator after the Australian Hotels Association had announced the establishment of its own rival fund, the Hospitality Organisations Superannuation Trust (HOST), a development which eventually led to the establishment of the joint national scheme HOST-PLUS. ${ }^{40}$ The Health Employees Superannuation Trust Australia (HESTA) was founded by the health unions after the Royal Australian Nursing Federation had originally approached National Mutual to administer their draft SupaNurse scheme. ${ }^{41}$ After calling for and receiving tenders from a number of mutuals, including both National Mutual and Jacques Martin, the Federated Clerks' Union (FCU) and the Shop, Distributive and Allied Employees' Association (SDA) contracted the AMP Society to help them establish the Clerical, Administrative and Retail Employees (CARE) superannuation fund in $1986 .{ }^{42}$ Similarly, the regional scheme Tasplan, created by the Tasmanian Trades and Labour Council and Confederation of Industries, was established with the help of Neil Cassidy, a seconded National Mutual manager. The regional fund Sunsuper, set up by the Trades and Labour Council of Queensland, the Australian Workers Union (AWU) and the Queensland Confederation of Industry, was almost completely dependent on Suncorp, with the recently privatised Queensland State Government Insurance Office providing their administration, insurance and investment facilities. ${ }^{43}$ In contrast, the Australian Superannuation Savings Employment Trust (ASSET), set up by the NSW Labour Council together with the SDA, the FCU, the NSW Employers' Federation and NSW Chamber of Manufactures, was initially administered by Westpac, the former Bank of New South Wales. ${ }^{44}$ Yet by 1988 , Jacques Martin was the administrator of 16 industry schemes while seven used AMP's Australian Administrative Services (AAS) and National Mutual Nexis had six as the late 1980s saw the life offices actively seek out business with the burgeoning union-established sector. ${ }^{45}$ Opportunity triumphed over professional and ideological

\footnotetext{
${ }^{39}$ Minutes, ACTU superannuation committee, 30 November 1979, box 234, VTHC collection, University of Melbourne Archives; John Benson, Cathy Brigden and Rhonda Smith, "Union Response to Employment Instability: A Case Study of the Meat Industry", Research Paper No. 129, Department of Economics, The University of Melbourne, 1985; Chris Northover, interview, 26 June 2015.

${ }^{40}$ Dick Riley, "Union Super Scheme PLUS For Members", The Liquor Trades Union Journal, 1986, no. 2, 2; Colin Walker, "National Overview", Australian Hotelier, March 1986, 12.

${ }_{41}$ "Superannuation and You", Australian Nursing Journal June 1987, 11-12; Fiona Kyle, "National Superannuation Scheme Launch", Australian Nursing Journal, September 1987, 14-15.

${ }^{42}$ AMP to John P. Maynes, 16 April 1986, John Maynes papers, box 203, book 103, State Library of Victoria.

43 "Launch of State-wide Super Fund", The Australian Worker, 29 September 1987, 7; "Sunsuper Basks in the SGC", Superfunds, April 1994, 25-27.

44 "ASSET" Australian Superannuation Savings Employment Trust, Newsletter no. 2, 23 September 1987, John Maynes Papers, box 293, book 104, State Library of Victoria; "Profile: Neil Cassidy", SuperTalk 17, 2015.

${ }^{45}$ Philippa Tyndale, "Industry Superannuation: Off the Boil, but Still Simmering", Superfunds, November 1988, 40-43.
} 
reservation as winning the administration business of a fund was seen as a potential avenue to gaining access to the schemes' more lucrative insurance and investment business.

Collaboration between the old mutual sector and the union movement was vital in securing support for the funds, in contrast to the opposition of the private market that undermined national superannuation reform in the UK. ${ }^{46}$ The industry funds advertised to members that they had the backing of established superannuation providers, unlike the earlier union schemes which had been much smaller and less complex to run. The AWU Superannuation Fund (established in 1976) had been the subject of scandal in 1979 when a loan from the AWU to its trustee AWU Finance Services Management had been raised in the federal parliament. ${ }^{47}$ And LUCRF was subject to similar intrigue when the Storemen and Packers' federal president Bill Landeryou had been forced to resign from the Cain cabinet after allegations of improper conduct had been made in the Victorian legislature. ${ }^{48}$ The involvement of the old mutuals in funds administration, however, was managed in a manner that enabled the union and employer association officials on the boards of the funds to remain in control in a way that employer trustees had not been able to under the bundled life-office model which had previously been dominant in the sector.

Rather than being so dependent on their life-insurance partners, the trustees of the industry funds, their fund secretaries and coordinators remained focussed on establishing a different kind of governance arrangement. As superannuation provisions were entered into industrial awards, industrial relations tribunals, both federal and state, preferred jointly governed superannuation schemes. Perhaps ironically, the industrial democracy model of fund governance adopted by BUS had resulted from a pragmatic decision made in order to sign employers up to the arrangement. ${ }^{49}$ Earlier union schemes such as the NSW Coal Mine Workers Pensions Fund (set up in 1941 after a royal commission and a six-week industrial campaign) had equal representation of employers and employees (with a state governmentappointed chair), but the Stevedoring Employees Retirement Fund (established on the recommendations of the Woodward report in 1967) had a majority of employer directors and the Pulp and Paper Workers' Superannuation Fund and LUCRF had both been founded with union majorities. ${ }^{50}$ Two of the larger industry funds, however, had been set up by employer

\footnotetext{
${ }^{46}$ Hugh Pemberton, “'What Matters is What Works': Labour's Journey from 'National Superannuation' to 'Personal Accounts"', British Politics 5, no. 1 (2010), 41-64.

${ }^{47}$ House Hansard, 5 April 1979, pp. 1661-66.

${ }^{48}$ Philip Chubb, "Cain Forces Landeryou Out", The Age, 1 September 1983, 1; M.E.J. Black, Advice to the Hon. John Cain, MP, Premier of Victoria, in the matter of the Honourable William Albert Landeryou, MLC, 25 October 1983, 204-6.

${ }^{49}$ Tom McDonald, interview, 23 March 2015.

${ }^{50}$ John A. Ferguson, Report of the Royal Commission into the Compulsory Retirement of Employees in Coal and Oil Shale Mines in New South Wales at the age of 60 years (Sydney: Govt Printer, 1941); Coal and Oil Shale Mine Workers (Pensions) Act 1941 (NSW); A. Edward Woodward, National Stevedoring Industry Conference, General Report (Sydney 1967); Charlie Fitzgibbon to ACTU, 2 February 1977, Superannuation Unions
} 
associations: the Australian Retirement Fund (ARF) had first been proposed by the Australian Chamber of Manufactures (ACM) and the Retail Employees Superannuation Trust (REST) was originally established by the Retail Traders Association. ${ }^{51}$ The partnership trustee model that emerged in industry super over the course of the 1980s was enshrined in law (at least for new funds) by the Occupational Superannuation Standards Act 1987. Dubbed the "representative model" by its advocates today, it was not connected by its union advocates with industrial democracy at the time nor was it viewed in terms of mutualism. Full industrial democracy proposals were still being promoted in the late 1980s for the public service and the union-employer partnerships on the boards of superannuation funds were only described in terms of industrial democracy by academics at the time. For unions mutualism was something associated with insurance firms and it was not spoken about in industry-funds circles other than in a dismissive manner. They had set out to reform superannuation provision by rejecting the employer-life office arrangement that had been predominant in the private sector since the 1950s and replaced it with a governance model of union-employer partnership in which the involvement of the life insurance mutuals was more clearly subordinate to union and member needs and concerns..$^{52}$

\section{Industry Superannuation as a Movement}

The shared union background of many of the funds' founders made it easy to conceive of the sector as a movement. In this regard too there were echoes of the early days of the old mutuals, when self-help and friendly societies had conceived of themselves in almost Messianic terms as the guarantors of collective welfare in a capitalist society. ${ }^{53}$ In Australia by the late 1980s, the industry superannuation sector was consolidated through the establishment of common industry bodies and concerted action in terms of advocacy and marketing as well the acceptance of a common identity as Industry Funds, underpinned by the pragmatic principle of "all profits to members".

Some 40 industry funds had been founded by the end of 1988 with almost 100 having

N147/321, NBAC; Greg Sword, "The Storemen and Packers' Union Superannuation Scheme", in Ronald Mendelsohn (ed.), Finance of Old Age (Canberra: ANU, 1986), 100; Margot Beasley, The Wharfies: A History of the Waterside Workers' Federation of Australia (Rushcutters Bay: Halstead, 1996), 207-25; Chris Northover, interview, 26 June 2015.

${ }^{51}$ Brendan O’Donohoe, "Unions Step Closer to Super Goal”, The Age, 16 December 1985, 1; Joe de Bruyn, interview, 7 April 2016.

${ }^{52}$ Diana Shaw, "Trade Union and Worker Participation in the Control of Superannuation Funds", in Ed Davis and Russell Lansbury (eds), Democracy and Control in the Workplace (Melbourne: Longman Cheshire, 1986), 192-215; Julian Teicher, "Employee Participation and Industrial Democracy in Australian Government Employment: 1983-1988" (PhD diss., Monash University, 1990).

${ }^{53}$ Jureidini, "Life Insurance and Superannuation", 41-49; Simon Cordery, British Friendly Societies, 1750-1914 (Basingstoke: Palgrave Macmillan, 2003), 29-41. 
appeared by $1991 .{ }^{54}$ The late $1980 \mathrm{~s}$, however, saw movement towards establishing the first of the collective institutions that are owned by the industry funds. In 1986, a group of union officials (including LUCRF's Sword and BUS's McDonald) had travelled to Europe with the support of the federal government's Trade Development Council to investigate how countries such as Sweden and West Germany had managed to retain both high levels of skills and employment, and had returned with a set of recommendations to transform Australian industry. A Special Unions Conference in November 1986 had adopted the resulting Australia Reconstructed report's recommendation that superannuation funds should be compelled to invest in national development projects through a publically controlled National Development Fund..$^{55}$ As assistant secretary of the ACTU, in 1988 Weaven had won agreement from the AMP and the ACM to set up an "Australian Investment Fund" to preempt government action, and in December 1990 the ACTU, the ACM and the AMP launched the $\$ 100$ million Development Australia Fund (DAF) to invest in projects which would help stimulate economic growth. ${ }^{56}$

Although managed by the AMP Society, DAF would be the first of a series of collective institutions set up by the ACTU and the leading industry funds in the early 1990s. In 1991, in collaboration with Jacques Martin and the trustees of public sector and company staff funds, the first annual Conference of Major Superannuation Funds (CMSF) was established, convened by Mavis Robertson, the ACTU's national industry superannuation coordinator and the Federated Engine Drivers and Firemen's Association's representative on the board of the Allied Unions Superannuation Trust (AUST). ${ }^{57}$ In 1992, the year of the passing of the superannuation guarantee legislation (enacted in order to raise the award contribution rate from 3 per cent to 9 per cent), the steering committee of the CMSF then established the Australian Institute of Superannuation Trustees (AIST) which would also be formally set up by Robertson with Court as its inaugural president. ${ }^{58}$ The Women in Super network was formed in 1993, again by Robertson in her role as convenor of CMSF, in the same year she concluded the merger of AUST and BUS as fund secretary of Construction and Building Unions Superannuation (C+BUS). ${ }^{59}$

By 1993 the industry funds and their collective institutions were coming to be referred to as a "movement" as CMSF and AIST became key networking venues for fund trustees and

\footnotetext{
${ }^{54}$ Beth Quinlivan, "Merging Industry Super Funds", Superfunds, September 1992, 29-33.

${ }^{55}$ Michael Easson, "Superannuation Funds and Investments - A Union View", Superfunds, December 1986, 914; ACTU/TDC, Australia Reconstructed: ACTU/TDC Mission to Western Europe; A Report by the Mission Members to the ACTU and TDC (Canberra: AGPS, 1987)..

${ }^{56}$ Garry Weaven, report to ACTU Executive, 22 August 1988, John Maynes papers, box 200, folder 47, State Library of Victoria; Barrie Dunstan, "Socially Desirable Super Fund Aims to Raise \$500m", Australian Financial Review, 6 December 1990, 5.

${ }^{57}$ Conference of Major Superannuation Funds central file, AIST archives.

${ }^{58}$ Minutes, AGM, Australian Institute of Superannuation Trustees, 28 March 1992, AIST archives.

59 "Women in Super: Background", November 1993, AIST archives.
} 
secretaries, as the schemes continued to develop and grow. ${ }^{60}$ The established superannuation sector remained largely hostile to the industry funds -- and even to the life office employees that had become involved with the industry movement. Yet in 1994 National Mutual approached the ACTU with a proposal to sell home loans to the members of the industry schemes in light of a proposal in the seventh Accord to allow Australians to use some of their superannuation to purchase a house. ${ }^{61}$ In that year Weaven (who had left the ACTU in 1990 to become a consultant) and the ACTU's Arthur Apted would similarly set up the Industry Super Property Trust (ISPT) to profit from the property crash of the early 1990s. Later in 1994, C+BUS and the Superannuation Trust of Australia (or STA as the Manufacturing Unions Superannuation Trust had been renamed in 1988) announced the establishment of a financial consulting business, Industry Fund Services (IFS), jointly funded by Jacques Martin and headed by Weaven. ${ }^{62}$ Two different types of collective institutions had developed -financial organisations such as those led by Weaven which were mostly wealth-management services focused and the representative bodies established by Robertson that predominantly had training, networking and advocacy functions. As chair of C+BUS, Court would also be instrumental in the 1995 relaunch of DAF (which eventually saw the fund break with AMP) at the same time as the Industry Funds Forum (an association of the movement's fund secretaries) trademarked the expression "Industry Superannuation Funds" and the first joint logo was adopted -- of a tree pruned in the shape of Australia. ${ }^{63}$ With the development of the collective institutions, a new identity was formed based around the notion that the funds were not-for-profit organisations, with STA and C+BUS often leading the new initiatives. In 1997 IFS hired Sandy Grant from Colonial Mutual who had worked alongside Weaven since the early days of BUS. Grant would start talking to Weaven about how the industry movement was becoming more and more like a new kind of mutual sector. ${ }^{64}$

\section{The New Mutualism}

The demutualisation of life insurance in Australia has usually been seen as a reflection of deregulation and the opening up of the finance industry to international competition. ${ }^{65}$ Two of the key demutualisations, however, those of City Mutual and National Mutual occurred in

\footnotetext{
60 "Fitzgerald Uproots Superannuation Again", Superfunds, October 1993, 9.

${ }^{61}$ ALP/ACTU, "Accord Agreement 1993-1996: "Putting Jobs First"” (Accord Mark VII), March 1993; ACTU Executive decision, May 1994, Workplace, Winter 1994, 5; Cathy Bolt, “ACTU Enters Mortgage Market”, Australian Financial Review, 19 April 1994, 38.

${ }^{62}$ Garry Weaven, "Discussion Paper - Opportunities for Property Investment", June 1993; "Industry Funds' Property Pool”, Superfunds, April 1994, 3; “Industry Funds Do It For Themselves”, Superfunds, July $1994,3$.

${ }^{63}$ Ian Court, interview, 18 November 2015.

${ }^{64}$ Sandy Grant, interview, 27 July 2015.

${ }^{65}$ Keneley, "Demise of the Mutual Life Insurer".
} 
response to prudential problems which had arisen due to an overreliance on selling capital guarantee products, many of which had been purchased by the industry funds ${ }^{66}$ City Mutual (then called Capita) had demutualised during its 1990 takeover by MLC (then owned by the property company Lend Lease) and National Mutual became a listed corporation as part of its 1995 absorption into the French insurance conglomerate AXA. Colonial Mutual and the AMP Society also demutualised in the late 1990s in light of a broader neoliberal abandonment of the principle of mutualism in life insurance. Mutualism was seen by both business leaders and government as incompatible with broader trends in late-twentiethcentury international finance.

Yet in 1999, Weaven publicly stated that the challenge for industry super in the next century was how to "earn the status of the "new mutuals"'. ${ }^{67}$ When Members Equity Bank was set up that year, based on the Super Members Home Loans joint venture, it was duly claimed by its chairman Bernie Fraser to be an organisation where the interests of clients (industry fund members) would be balanced with the owners (the industry funds). ${ }^{68}$ By this stage a former Jacques Martin manager, Helen Hewett had become the CEO of C+BUS and Ian Silk, the former Victorian manager of AMP's AAS, had similarly taken over as fund secretary of ARF. Louise Davidson had joined IFS from National Mutual to set up many of its members services and Members Equity was headed by the former National Mutual manager Anthony Wamsteker. ${ }^{69}$ The trade unionists who had dominated most of the industry funds (with the exception of employer-founded schemes such as REST) were joined by staff from the old mutual sector in the years before it disappeared. Most of the early fund secretaries and coordinators were former union officials, but the influence of Colonial, AMP and National Mutual on the funds and their collective institutions was clear. In 1997, Colonial Mutual had even agreed to re-establish their industry funds administration arm as a joint venture with IFS -- and Jacques Martin Industry Funds Administration (JMIFA) would eventually be renamed Superpartners after IFS bought out the rest of JMIFA when the demutualised Colonial Ltd was acquired by the Commonwealth Bank..$^{70}$ ARF's CEO Silk had been one of the main opponents of calling the industry funds "not for profits", maintaining that the funds were very much in the business of making profits for their members. ${ }^{71}$ But even

\footnotetext{
${ }^{66}$ Catherine Armitage, "MLC Swallows Capita", Sydney Morning Herald, 19 April 1990, 30; Max Walsh, "Hoskins' Burden: To Quell the Niggling", Sydney Morning Herald, 28 May 1992, 33; Weaven, "Workers' Capital".

${ }^{67}$ Garry Weaven, quoted in Barrie Dunstan, "Funds Body Looks for a Way to Diversify", Australian Financial Review, 25 February 1999, 26.

${ }^{68}$ Industry Fund Services, Report to Industry Superannuation Funds, September 2001, 4.

${ }^{69}$ Ian Silk, interview, 10 August 2015; Louise Davidson, interview, 2 December 2015.

${ }^{70}$ Maureen Murrill, "Jacques Martin Finally Goes Quietly with IFS", Business Review Weekly, 29 September 1997, 49.

${ }^{71}$ Ian Silk, interview, 10 August 2015.
} 
still, the label "mutual" has only ever been embraced problematically by the newcomers to the finance sector.

Rather than using the term "mutual", the industry funds joint advertising campaign adopted the description "all profits to members", leaving expressions such as "mutual basis" and "mutual in character" for official documents. The Industry Super Network was formally established in 2006 as part of Members Equity Bank to run the joint industry-fund marketing campaign, particularly the "Compare the Pair" ads that had originally been commissioned by IFS (on behalf of the short-lived Industry Funds Network). ${ }^{72}$ DAF was merged with the relevant section of IFS in 2004 and reconstituted as Industry Funds Management (now IFM Investors) with Weaven succeeding Court as chair. As the industry funds purchased more and more privatised airports and toll roads, Weaven came to speak of the IFM model as supporting the "mutualisation of infrastructure". ${ }^{73}$

In 2005, the independent advisor SuperRatings was asked to supply performance metrics to help promote the industry funds and to the surprise of their CEO Jeff Bresnahan it discovered that the not-for-profit schemes were dominating the performance surveys. ${ }^{74}$ The early 2000s had seen the four main commercial banks acquire most of the remains of the old mutual sector, but the investment performance of the retail end of the superannuation industry had been so poor that in late 2010 the Gillard government intervened in the market to force the banks and the demutualised AMP to offer low-cost "MySuper" products which mimicked the default service offered by the industry funds. ${ }^{75}$ In contrast, the traditional mutual industry has continued to decline, with Australian Unity (the product of the 1993 merger of the Australian Natives' Association and Manchester Unity) the main flag-bearer among the surviving friendly societies. Most of the country's credit cooperatives and building societies were absorbed into the commercial banking sector in the 1990s, leaving Australia with one of the smallest traditional mutual sectors internationally. ${ }^{76}$ The industry superannuation funds have become the most successful and vibrant providers of not-for-profit financial services in Australia.

Yet the spectre of the collapse of the old mutuals and their transformation into the wealth management arms of the commercial banks is also now used to defend the industry sector. In late 2015 the Coalition government tried to legislate to weaken the influence of unions on the boards of industry funds under the guise of promoting directorial independence.

\footnotetext{
${ }^{72}$ Christine St Anne, A Super History: How Australia's 1 Trillion+ Superannuation Industry Was Made (Melbourne: Major Street Publishing, 2012), 213-14.

73 Industry Fund Services, Report to Industry Superannuation Funds, August 2004, 6; Garry Weaven, "Mutualisation of Infrastructure: Using Superannuation to Provide our Future Needs" (paper presented to the Industry Super Australia, Innovation in Infrastructure - Beyond the G20 symposium, March 2015).

${ }^{74}$ Jeff Bresnahan, communication, 29 June 2016.

${ }^{75}$ Bill Shorten, press release, 16 December 2010; Superannuation Legislation Amendment (MySuper Core Provisions) Act 2012 (Cth).

${ }^{76}$ Reserve Bank of Australia, Financial Stability Review, March 2006, 52-53.
} 
At the time, ACTU president Ged Kearney raised the fate of the old mutuals in her defence of the representative governance model. ${ }^{77}$ Many industry superannuation pioneers remain worried that the funds might also one day lose their commitment to being "profit for members" institutions and go down a similar path of demutualisation. Established in opposition to the employer-provider tradition dominated by the life insurance mutuals, the industry superannuation sector has adopted the legacy of mutualism to legitimise its standing and to defend itself from conservative attack. The industry funds have been outstanding financial successes, but maintaining their identity through narratives and history remains a key concern of the older generation of industry superannuation pioneers who see the background of the sector in a reforming movement as essential to its future prospects.

\section{Conclusion}

Founded during the industrial campaigns of the 1980s, industry superannuation funds were first characterised by their proponents as union-employer partnerships in contrast to the previously dominant model of employer-insurance mutual arrangement. As the last of the old life offices demutualised, however, the industry sector came more and more to assume their former role as "third-sector" finance firms, as member-focused organisations that returned all their profits to superannuation fund members. As the industry super sector grew in the 1990s, the description mutual was claimed by the industry funds, although not in their marketing campaigns where "all profits to members" (recently recast as "profit for members") became the favoured collective description. Having a problematic relationship with the legacy of the old mutuals, however, the mutualistic nature of the industry funds and the associated institutions they own remains a key feature of the identity that they ascribe to themselves over 30 years after the sector was founded with the establishment of Building Unions Superannuation.

\section{Acknowledgments}

This paper was produced as part of the "Workers' Capital" project at RMIT, funded by the Australian Institute of Superannuation Trustees with the support of Industry Super Holdings. Some of the interviews were (co-)conducted by Cathy Brigden and Eleanor Bentham helped with some of the archival work.

\footnotetext{
${ }^{77}$ Ged Kearney, "Tragedy if Member-owned Super Follows the Fate of Mutuals", Australian Financial Review, 23 October $2015,39$.
} 
Table 1: Industry superannuation funds

\begin{tabular}{|c|c|c|c|c|}
\hline Fund & $\begin{array}{l}\text { Date } \\
\text { established }\end{array}$ & Union sponsor & $\begin{array}{l}\text { Successor fund } \\
\text { today }\end{array}$ & $\begin{array}{l}\text { Main union } \\
\text { today }\end{array}$ \\
\hline $\begin{array}{l}\text { Allied Unions } \\
\text { Superannuation Trust }\end{array}$ & 1984 & $\begin{array}{l}\text { construction } \\
\text { unions }\end{array}$ & Cbus & CFMEU \\
\hline $\begin{array}{l}\text { Australian } \\
\text { Retirement Fund }\end{array}$ & 1986 & ACTU & AustralianSuper & ACTU \\
\hline $\begin{array}{l}\text { Australian } \\
\text { Superannuation } \\
\text { Savings Employment } \\
\text { Trust (ASSET) }\end{array}$ & 1987 & $\begin{array}{l}\text { NSW Trades } \\
\text { and Labour } \\
\text { Council }\end{array}$ & CARE Super & ASU \\
\hline $\begin{array}{l}\text { Building Unions } \\
\text { Superannuation } \\
\text { (BUS) }\end{array}$ & 1984 & building unions & Cbus & CFMEU \\
\hline $\begin{array}{l}\text { Clerical, } \\
\text { Administrative and } \\
\text { Retail Employees } \\
\text { Superannuation Fund } \\
\text { (CARE) }\end{array}$ & 1986 & $\begin{array}{l}\text { Federated } \\
\text { Clerks' Union, } \\
\text { SDA }\end{array}$ & CARE Super & ASU \\
\hline $\begin{array}{l}\text { Coal Mine Workers } \\
\text { Pensions Fund } \\
(\mathrm{NSW})\end{array}$ & 1941 & $\begin{array}{l}\text { Miners' } \\
\text { Federation }\end{array}$ & $\begin{array}{l}\text { Mine Wealth + } \\
\text { Wellbeing }\end{array}$ & CFMEU \\
\hline $\begin{array}{l}\text { Health Employees } \\
\text { Superannuation Trust } \\
\text { Australia (HESTA) }\end{array}$ & 1987 & health unions & HESTA & $\begin{array}{l}\text { HSU, ANMF, } \\
\text { ASU }\end{array}$ \\
\hline $\begin{array}{l}\text { Labour Union Co- } \\
\text { operative Retirement } \\
\text { Fund (LUCRF) }\end{array}$ & 1978 & $\begin{array}{l}\text { Federated } \\
\text { Storemen and } \\
\text { Packers' Union }\end{array}$ & LUCRF Super & NUW \\
\hline $\begin{array}{l}\text { Meat Industry } \\
\text { Employees' }\end{array}$ & 1981 & AMIEU & $\begin{array}{l}\text { Meat Industry } \\
\text { Employees' }\end{array}$ & AMIEU \\
\hline
\end{tabular}




\begin{tabular}{|c|c|c|c|c|}
\hline Provident Fund & & & $\begin{array}{l}\text { Superannuation } \\
\text { Fund (MIESF) }\end{array}$ & \\
\hline $\begin{array}{l}\text { Metal Unions } \\
\text { Superannuation } \\
\text { Trust/Superannuation } \\
\text { Trust of Australia }\end{array}$ & 1986 & $\begin{array}{l}\text { Metal Trades } \\
\text { Federation of } \\
\text { Unions }\end{array}$ & AustralianSuper & ACTU \\
\hline $\begin{array}{l}\text { Portable Liquor } \\
\text { Union } \\
\text { Superannuation } \\
\text { Scheme (PLUS) }\end{array}$ & 1987 & $\begin{array}{l}\text { Liquor Trades } \\
\text { Union }\end{array}$ & HOST-PLUS & United Voice \\
\hline $\begin{array}{l}\text { Pulp and Paper } \\
\text { Workers' } \\
\text { Superannuation Fund }\end{array}$ & 1974 & $\begin{array}{l}\text { Pulp and Paper } \\
\text { Workers' } \\
\text { Federation }\end{array}$ & First Super & CFMEU \\
\hline $\begin{array}{l}\text { Retail Employees } \\
\text { Superannuation Trust } \\
\text { (REST) }\end{array}$ & 1987 & SDA & REST Super & SDA \\
\hline $\begin{array}{l}\text { Stevedoring } \\
\text { Employees } \\
\text { Retirement Fund }\end{array}$ & 1967 & $\begin{array}{l}\text { Waterside } \\
\text { Workers' } \\
\text { Federation }\end{array}$ & Maritime Super & $\begin{array}{l}\text { Maritime } \\
\text { Union of } \\
\text { Australia }\end{array}$ \\
\hline Sunsuper & 1987 & $\begin{array}{l}\text { Trades and } \\
\text { Labour Council } \\
\text { of Queensland, } \\
\text { AWU }\end{array}$ & Sunsuper & $\begin{array}{l}\text { Queensland } \\
\text { Council of } \\
\text { Unions }\end{array}$ \\
\hline Tasplan & 1987 & $\begin{array}{l}\text { Tasmanian } \\
\text { Trades and } \\
\text { Labour Council }\end{array}$ & Tasplan & $\begin{array}{l}\text { Unions } \\
\text { Tasmania }\end{array}$ \\
\hline
\end{tabular}

